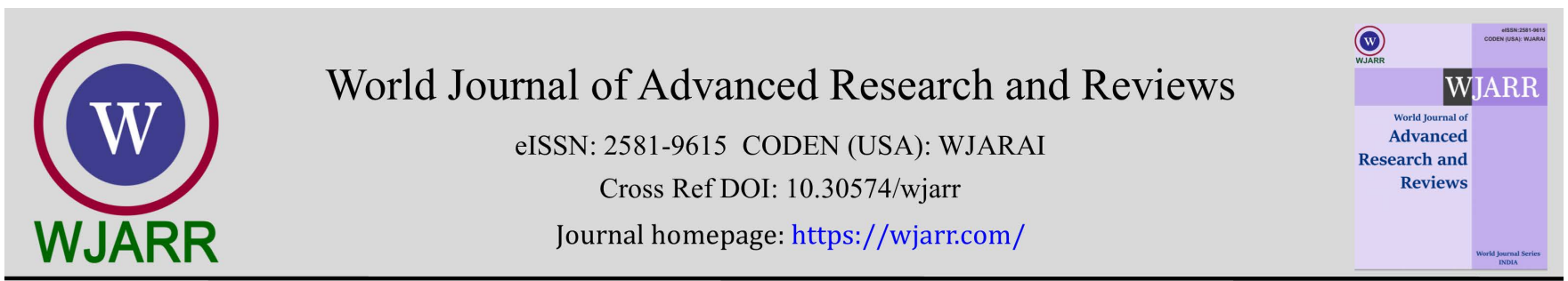

(RESEARCH ARTiClE)

\title{
Budgeting practices and absorption rate of devolved funds by County Government of Nyeri
}

\author{
Rhoda Kawira Ngai * Antony Kimathi and Moses Kithinji \\ School of Business and Economics, Kenya Methodist University, Kenya.
}

World Journal of Advanced Research and Reviews, 2021, 11(03), 146-151

Publication history: Received on 19 July 2021; revised on 28 August 2021; accepted on 30 August 2021

Article DOI: https://doi.org/10.30574/wjarr.2021.11.3.0395

\begin{abstract}
Absorption rate is a vital tool in determining the efficiency and general performance of the counties as regards utilization of the intended funds. A majority of counties absorbed less than 50 percent of their budgets in the first nine months of the 2018-2019 financial year. Nyeri County had a development absorption rate of only $21.1 \%$. This study therefore sought to establish the influence of budgeting practices on absorption rate of devolved funds by county government of Nyeri. This study used descriptive survey design. The target population for this study comprised 34 senior officers in the department of finance and economic planning in Nyeri County. A census of all 34 senior officers in the department of finance and economic planning was conducted. A self-administered questionnaire was used to collect data. Descriptive statistics such as frequencies, percentages, mean and standard deviation was used to describe the results in the study. Chi-square tests were used to find the relationships with the help of statistical package for social sciences. The findings show that the county government of Nyeri had good budgeting practices. There was a significant relationship ( $\chi 2=44.316, \mathrm{df}=21, \mathrm{p}=0.02)$ between budgeting practices and absorption rate of devolved funds by county government of Nyeri. The study concludes that budgeting practices influence absorption rate of devolved funds by county government of Nyeri. The study therefore recommends that the county government ought to pass budgets in conformity with the cash disbursement schedules.
\end{abstract}

Keywords: Absorption rate; Budgeting practices; County governments; Devolution

\section{Introduction}

Absorption rate refers to the share of the actual expenditure out of the budgeted expenditure (the target) (KersanŠkabić \& Tijanić, 2017). The share is a vital tool in determining the efficiency and general performance of the counties as regards utilization of the intended funds. According to Achim and Borlea (2015), a higher absorption rate is preferred since it means that counties are close to their target. On the other hand, a low absorption rate implies that counties are performing below par in terms of utilization of the intended expenditure.

Globally the level of absorption is low $(<50 \%)$. Countries with a high marginal propensity to consume tend to have a high absorption rate. For example, the UK and the US have had a high level of absorption. The average absorption rate in the European Union is 27\% (Zaman \& Cristea, 2011). With an absorption rate of 100 per cent for the European Regional Development Fund (ERDF), the Cohesion Fund (CF) and the European Social Fund (ESF), Malta registered the highest level of success in the use of EU funds as it utilized fully the €987 million allocation for the 2007-13 period. Cyprus is first amongst the 28 EU countries in absorbing 46\% of the funds allocated by the European Regional Development fund. Romania's total absorption rate at the end of 2018 was 26 percent (Kersan-Škabić \& Tijanić, 2017).

\footnotetext{
* Corresponding author: Rhoda Kawira Ngai

School of Business and Economics, Kenya Methodist University, Kenya. 
In Africa, the absorption rate is even lower. According to Akinzika (2018), low absorption of funds within Global Fund grants has been a persistent and pervasive challenge in grant implementation, especially in sub-Saharan Africa, which receives about two third of Global Fund investment. A total of 20 countries, of which 18 are African, have low absorptive capacity. Government Spending Watch (GSW) 2015, which draws on data for 31 developing countries, showed that for 2012 and 2013, the water, sanitation and hygiene sector recorded greater under-spending on average than sectors including education, health, agriculture and environment, with more than a quarter of planned spending unused in 2012.

The Constitution of Kenya creates a decentralized system of government wherein two of the three arms of government; namely the Legislature and the Executive are devolved to the 47 Political and Administrative Counties as provided for under Article 6 and specified in the First Schedule (Republic of Kenya, 2010). One of the main purposes of devolution was to bring public finances closer to citizens in a manner that would allow them to have a say on how county budgets were planned for and used (Were, 2017). The Kenya government has laid out an elaborate institutional and regulatory framework providing support for public finance management in national and county governments. This derives from the Constitution of Kenya 2010, various Acts of Parliament, and other regulations (Kerich, 2017).

The sources of county government revenue in Kenya include revenue received from the national government, revenue generated locally, and revenue from external sources (Gituma, 2017). The equitable share is the money parliament shares vertically between the national and the county governments. The money comes from the ordinary tax revenue the national government raises nationally. The county governments can also receive additional allocations from the national government's equitable share of revenue (from the vertical sharing). These additional allocations are known as conditional allocations or conditional grants (Ngicuru, Muiru \& Riungu, 2016). For devolved funds to be put into good use, a high absorption rate is necessary.

Nyeri County is one of the 47 counties in Kenya. It is located in the Mount Kenya Region. The county headquarters are located in Nyeri town. According to the 2019 Kenya Population and Housing Census (KPHC), the county has a population of 759,164 people with a population density of 208 people per $\mathrm{Km}^{2}$ (Kenya National Bureau of Statistics (KNBS) (2020). In the 2018-2019 financial year, the county raised 1B shilling from local sources and received 6.7B from external sources which includes the national transfers and grants (County Government of Nyeri, 2020). In the 2019-2020 budget, the county allocated a development expenditure worth 2.5B which represented 32.08 percent of the total budget. However, the Controller of Budget (2020) reports that the county registered a paltry $3.8 \%(115 \mathrm{M})$ in development expenditure. The reasons for the low absorption rate are unclear and a study into the determinants of absorption rate of devolved funds was timely.

A majority of counties absorbed less than 50 percent of their budgets in the first nine months of the 2018-2019 financial year (CoB, 2019). The report shows that for every Sh100 that the devolved units received from the Exchequer to build roads, schools, hospitals, improve sewer lines, distribute water or construct market stalls in the first nine months of Financial Year 2018/19, Sh76 went untouched. Unsurprisingly, absorption of recurrent budgets is much higher than that of development budgets. The range for recurrent is from 80 to 95 percent, while development ranges from 59 to 76 percent (Lakin \& Kinuthia, 2019). Nyeri County had an overall absorption rate of 50.5\% with development absorption rate of only $21.1 \%$. This study therefore sought to establish the influence of budgeting practices on absorption rate of devolved funds by county government of Nyeri

$\mathrm{HO}_{1}$ There is no significant relationship between budgeting practices and absorption rate of devolved funds by county government of Nyeri.

\section{Material and methods}

This study used descriptive survey design. Descriptive research is justified as it aims to accurately and systematically describe a population, situation or phenomenon. The target population for this study comprised 34 senior officers in the department of finance and economic planning in Nyeri County. These persons were targeted because they are involved in the decision making and execution of budgeting, internal controls and procurement practices. A census of all 34 senior officers in the department of finance and economic planning was conducted. Results of a census are also more reliable as they are free of sampling bias.

A self-administered questionnaire was used to collect data. Questionnaires were preferred as they are able to collect a large amount of information from a large population in relatively short amount of time. Prior to data collection in the study, a pre-test was conducted. To ensure content validity of the instrument, the researcher had her supervisor and a statistician review the questionnaire to certify that the questions would yield valid data. Criterion validity was 
established via analysis of the data collected in the pre-test using correlation analysis. In this study, reliability was established through analysis of pre-test data.

Data collected from the pre-test was fed into a computer using the statistical package for social sciences (SPSS) version 23 for windows. The data was subjected to scale analysis using the Cronbach alpha as an indicator for internal consistency as recommended by Hennink, Hutter and Bailey (2011). Items with a coefficient of 0.7 and below were rephrased or removed altogether. Descriptive statistics such as frequencies, percentages, mean and standard deviation were used to describe the results in the study. Chi-square tests were used to find the relationships

\section{Results}

A total of 31 senior officers in the department of finance and economic planning were involved in the study. This represents a $91 \%$ response rate.

\subsection{Socio-Demographic Characteristics}

The findings show that majority $(64.5 \%)$ of the respondents were male. This shows that there was a great gender disparity in the department of finance and economic planning of Nyeri County whereby women were underrepresented. As shown in Table 1, 38.7\% of the respondents were aged between 31 and 40 years while those aged between 41 and 50 years accounted for $29 \%$. The mean age was 35 years. This mean that majority of employees in the department of finance and economic planning of Nyeri County were youth. On education, the results show that slightly less than half (48.4\%) had acquired a diploma while $32.3 \%$ had acquired a bachelor's degree as their highest level of education. These findings therefore show that employees in the department of finance and economic planning of Nyeri County are highly educated as they have all acquired post-secondary education. Slightly above half (54.8\%) of the respondents were accountants while $32.3 \%$ were managers. This was expected as most of the roles of employees in the department of finance and economic planning of Nyeri County has to do with accounting and business management. Results in Table 1 also show that the vast majority (90.3\%) of respondents had over 5 years of working experience in the county. This was good for the study as it means that majority of the respondents in the study are well experienced and knowledgeable of the county government roles, processes and activities which would enable them give reliable information on the subject matter of the study.

Table 1 Socio-Demographic Characteristics

\begin{tabular}{|l|c|c|c|}
\hline \multicolumn{1}{|c|}{ Characteristic } & Categories & Frequency & Percent \\
\hline Gender & Male & 20 & 64.5 \\
\hline Age (years) & Female & 11 & 35.5 \\
\hline & $21-30$ & 12 & 19.4 \\
\hline & $31-40$ & 9 & 38.7 \\
\hline Level of education & $41-50$ & 4 & 29.0 \\
\hline & $>51$ & 15 & 12.9 \\
\hline & Diploma & 10 & 48.4 \\
\hline Profession & Bachelor's degree & 6 & 32.3 \\
\hline & Postgraduate degree & 17 & 19.4 \\
\hline & Accountants & 10 & 54.8 \\
\hline Working experience(years) & Managers & 4 & 32.3 \\
\hline & Others & 3 & 12.9 \\
\hline
\end{tabular}




\subsection{Budgeting Practices}

Results in Table 2 show that majority (80.6\%) of the respondents agreed that the budget process of the county government consist of integrated development planning. All $(100 \%)$ respondents agree that quarterly reports on budget implementation are prepared. Majority (83.9\%) of the respondents agreed that there are provisions for monitoring and evaluation and clear reporting mechanisms. Similarly, $90.3 \%$ agree that county government passes budgets in conformity with County Allocation of Revenue Act. However, slightly above half (54.8\%) disagree that the county government passes budgets in conformity with the cash disbursement schedules.

Majority (87.3\%) agreed that programme-based budget estimates are used. Majority (61.3\%) agreed that County budgets clearly show the link between outputs and outcomes. Majority (77.4\%) agreed that County Budget Estimates have important details in terms of presentation of expenditure information by economic classification. Majority (87.1\%) agreed that there is ample public participation in budgeting process. Similarly, $83.9 \%$ agree that there are active County Budget and Economic Forums (CBEFs) in the county. All (100\%) agreed that budgeting information is shared with the public. An equal number (100\%) agreed that County Fiscal Strategy Paper (CFSP) and the County Budget Estimates are accessible online. Respondents in the study were also asked to indicate what challenges they experience in budgeting making implementation. Challenges cited by respondents included political interference, low public participation and IFMIs challenges.

\section{Table 2 Budgeting Practices}

\begin{tabular}{|l|c|c|c|}
\hline & Agree & Uncertain & Disagree \\
\hline $\begin{array}{l}\text { The budget process of the county government consist of } \\
\text { integrated development planning }\end{array}$ & 80.6 & 9.7 & 9.7 \\
\hline $\begin{array}{l}\text { Quarterly reports on budget implementation are } \\
\text { prepared }\end{array}$ & 100.0 & 0.0 & 0.0 \\
\hline $\begin{array}{l}\text { There are provisions for monitoring and evaluation and } \\
\text { clear reporting mechanisms. }\end{array}$ & 83.9 & 12.9 & 3.2 \\
\hline $\begin{array}{l}\text { The county government passes budgets in conformity } \\
\text { with County Allocation of Revenue Act }\end{array}$ & 90.3 & 3.2 & 6.5 \\
\hline $\begin{array}{l}\text { The county government passes budgets in conformity } \\
\text { with the cash disbursement schedules }\end{array}$ & 29.0 & 16.1 & 54.8 \\
\hline Programme-Based Budget Estimates are used & 87.1 & 0.0 & 12.9 \\
\hline $\begin{array}{l}\text { County budgets clearly show the link between outputs } \\
\text { and outcomes }\end{array}$ & 61.3 & 32.3 & 6.5 \\
\hline $\begin{array}{l}\text { County Budget Estimates have important details in terms } \\
\text { of presentation of expenditure information by economic } \\
\text { classification }\end{array}$ & 77.4 & 9.7 & 12.9 \\
\hline There is ample public participation in budgeting process & 87.1 & 0.0 & 12.9 \\
\hline $\begin{array}{l}\text { There are active County Budget and Economic Forums } \\
\text { (CBEFs) in the county }\end{array}$ & 83.9 & 6.5 & 9.7 \\
\hline Budgeting information is shared with the public & 100.0 & 0.0 & 0.0 \\
\hline $\begin{array}{l}\text { The County Fiscal Strategy Paper (CFSP) and the County } \\
\text { Budget Estimates are accessible online }\end{array}$ & 100.0 & 0.0 & 0.0 \\
\hline
\end{tabular}

\subsection{Relationship between Budgeting and Absorption Rate}

Results in Table 3 show that there was a significant relationship $(\chi 2=44.316, d f=21, p=0.02)$ between budgeting practices and absorption rate of devolved funds by county government of Nyeri. The first hypothesis $\left(\mathrm{H}_{1}\right)$ is therefore rejected and the study concludes that there is a significant relationship between budgeting practices and absorption rate of devolved funds by county government of Nyeri. 
Table 3 Relationship between Budgeting and Absorption Rate

\begin{tabular}{|l|c|c|c|}
\hline & Value & df & $\begin{array}{l}\text { Asymp. Sig. (2- } \\
\text { sided) }\end{array}$ \\
\hline Pearson Chi-Square & $44.316^{\mathrm{a}}$ & 21 & 0.002 \\
\hline Likelihood Ratio & 23.917 & 21 & 0.297 \\
\hline Linear-by-Linear Association & 1.599 & 1 & 0.206 \\
\hline N of Valid Cases & 31 & & \\
\hline
\end{tabular}

\section{Discussion}

This study sought to establish the influence of budgeting practices on absorption rate of devolved funds by county government of Nyeri. The findings show that the county government of Nyeri had good budgeting practices. This is because most of budget planning, implementation, monitoring and evaluation requirements were met. This finding is in agreement with Orina et al. (2019) who in a similar study found that cash flows were important to budgetary allocation in counties; the county governments had reports of actual monthly cash flows, as a means of identifying patterns for monitoring cash flows. The findings are however in disagreement with Kibunja (2017) who in a study in Murang'a County Government in Kenya found that budget evaluation processes were not very effective since county financial reports were not timely, with oversight being poor. Similarly, the findings are in disagreement with findings of Mathenge et al. (2018) study, which found out that budget implementation encountered a lot of challenges including insufficient funds, institutional weakness, method of budget allocation unsatisfactory and implementing projects not budgeted.

There was a significant relationship $(\chi 2=44.316, \mathrm{df}=21, \mathrm{p}=0.02)$ between budgeting practices and absorption rate of devolved funds by county government of Nyeri. The results show that budgeting practices are an enabling factor whereby better budgeting practices lead to increased absorption rate. This consistent with findings of Kathungu (2016) whereby joint budget utilization including the budgeted county expenditure to the budgeted county revenues, actual county expenditures to actual county revenues and county resources to the county poverty index had a positive influence on the financial performance of the counties. Samira (2018) also found that budgeting process has an impact to improved financial performance at the County Government of Kwale in Kenya.

\section{Conclusion}

The study concludes that budgeting practices influence absorption rate of devolved funds by county government of Nyeri. Specifically, good budgeting practices increase the absorption rate of devolve funds. Good budgeting practices namely budget planning, implementation, monitoring and evaluation enable higher absorption rate because the county government can plan for projects better. In addition, the county government is able to monitor progress better and make amendments where necessary. However, this study found that county government of Nyeri did not prepare budgets in line with cash disbursement schedules which are irregular and unpredictable and this may explain in part the low absorption rates. The study therefore recommends that the county government ought to pass budgets in conformity with the cash disbursement schedules.

\section{Compliance with ethical standards}

\section{Disclosure of conflict of interest}

No conflict of interest.

\section{Statement of informed consent}

Informed consent was obtained from all individual participants included in the study. 


\section{References}

[1] Achim MV, Borlea SN. Determinants of the European funds absorption 2007-2013 in the European Union member states. [Adobe Digital Editions version]. 2015.

[2] Controller of Budget. Annual report and financial statements for the financial year ended. 30 June 2019.

[3] Gituma HK. Determinants of effective revenue collection by Embu County, Kenya (Doctoral dissertation, University of Embu). 2017.

[4] Hennink M, Hutter I, Bailey A. Qualitative Research Methods. Sage Publications, London, Los Angeles, New Delhi, Singapore, Washington DC. 2011.

[5] Kersan-Škabić I, Tijanić L. Regional absorption capacity of EU funds, Economic Research-Ekonomska Istraživanja. 2017; 30(1): 1191-1208.

[6] Kibunja EW. Budgetary process and financial performance of Murang'a county government, Kenya (Doctoral dissertation, Kenyatta University). 2017.

[7] Mathenge MS, Shavulimo PM, Kiama M. Financial Factors Influencing Budget Implementation in Counties (A Survey of Selected Counties in Kenya). Research Journal of Finance and Accounting. 2018; 9(1): 44-75.

[8] Ngicuru PN, Muiru MM, Riungu I. Effect of selected factors affecting revenue collection in Nairobi city county government. American Journal of Finance. 2016; 1(1): 1-10.

[9] Orina SM, Obwogi J, Nasieku TM. Factors Affecting Budgetary Allocation In The County Governments In Kenya. Strategic Journal of Business \& Change Management. 2019; 6(2).

[10] Republic of Kenya. The Constitution of the Republic of Kenya. 2010.

[11] Samira SA. Effect of Budgeting Process on Financial Performance of County Government of Kwale in Kenya. 2018.

[12] Wanjugu BW, Kiarie DM, Marendi P. Effects of Inspection of Purchases On Procurement Performance in Level Four Public Hospitals in Nyeri County. International Journal of Human Resources and Procurement. 2018; 7(4): $75-87$.

[13] Were A. Problems with financial accountability in counties. 2017.

[14] Zaman G, Georgescu G. The absorption of EU structural and cohesion funds in Romania: International comparisons and macroeconomic impact. [Adobe Digital Editions version]. 2014. 